\title{
PENINGKATAN KINERJA PERAWAT PELAKSANA MELALUI KOMUNIKASI ORGANISASI DI RUANG RAWAT INAP RUMAH SAKIT
}

\author{
Yulistiana Rudianti ${ }^{1,2^{*}}$, Hanny Handiyani ${ }^{3}$, Luknis Sabri ${ }^{4}$
}

1. STIKES Katolik St. Vincentius A Paulo, Surabaya 60008, Indonesia

2. Program Studi Magister, Fakultas Ilmu Keperawatan, Universitas Indonesia, Depok 16424, Indonesia

3. Fakultas Ilmu Keperawatan, Universitas Indonesia, Depok 16424, Indonesia

4. Fakultas Kesehatan Masyarakat, Universitas Indonesia, Depok 16424, Indonesia

*E-mail: devinassps@yahoo.com

\begin{abstract}
Abstrak
Komunikasi organisasi merupakan proses yang memberikan manfaat untuk peningkatan kinerja karyawan. Penelitian ini bertujuan untuk mengetahui hubungan antara komunikasi organisasi dan kinerja perawat pelaksana. Desain penelitian menggunakan korelasi deskriptif dengan pendekatan cross sectional terhadap 156 perawat pelaksana di ruang rawat inap. Instrumen penelitian memiliki reliabilitas 0,8716-0,8776. Hasil uji Chi square membuktikan adanya hubungan antara komunikasi organisasi dengan kinerja perawat pelaksana $(\mathrm{p}=0,046 ; \alpha=0,05)$. Variabel yang paling berpengaruh terhadap kinerja perawat pelaksana adalah supervisi dan pengarahan. Upaya meningkatkan komunikasi organisasi dengan cara melakukan supervisi dan pengarahan sesuai pedoman perlu dilakukan sehingga dihasilkan kinerja yang semakin baik.
\end{abstract}

Kata kunci: kinerja, komunikasi organisasi, pengarahan, perawat, supervisi

\begin{abstract}
Nurse Staff Performance Promoting through Organization Communications in the Hospital Ward. Organization communication is a process which is useful for improving the quality of staff performance. The purpose of this study is to determine the relationship between organization communication and performance of the nurse staff. The design was descriptive correlation with cross sectional approach involving 156 respondents. The reliability of questionnaire is 0.8716-0.8776. The result with chi square test showed that there is a relationship between communication organization and performance of nursing staff $(p=0.046 ; \alpha=0.05)$. The most influencing factors are supervision and direction. Increasing organization communication through supervision and direction is needed to promote a better performance.
\end{abstract}

Keywords: directio, nurse, organization communication, performance, supervision

\section{Pendahuluan}

Kinerja sebagai hasil kegiatan individu atau kelompok dalam suatu organisasi merupakan hal penting yang menunjukkan keberhasilan pelaksanaan sistem manajemen. Fried dan Fottler (2008) menyebutkan penilaian kinerja merupakan unsur kunci dari pelaksanaan manajemen. Hasil penilaian kinerja individu dapat memberikan gambaran pelaksanaan sistem manajemen oleh suatu organisasi untuk mencapai tujuan organisasi. salah satunya adalah organisasi rumah sakit.
Rumah sakit sebagai suatu organisasi mempunyai tujuan untuk memberikan pelayanan kesehatan yang berkualitas dan sesuai kebutuhan masyarakat dengan melibatkan semua bagian dalam organisasi termasuk perawat. Perawat sebagai tenaga kesehatan yang memberikan pelayanan secara terus menerus dan langsung dirasakan oleh pasien mempunyai peran penting untuk mewujudkan tujuan organisasi dengan memberikan pelayanan keperawatan yang optimal. Swansburg dan Swansburg (1999) menyebutkan bahwa penilaian kinerja perawat merupakan proses kontrol kualitas pelayanan 
keperawatan berdasarkan standar-standar tertentu praktik keperawatan. Dengan demikian, organisasi atau manajemen perlu mengadakan suatu evaluasi berupa penilaian kinerja berdasarkan standar tertentu praktik keperawatan.

Interaksi dalam organisasi membutuhkan suatu koordinasi dengan berbagai cara melalui komunikasi sehingga individu atau kelompok dalam organisasi menjadi bagian yang terintegrasi untuk mencapai satu tujuan. Ivancevich (1999) menyebutkan komunikasi organisasi adalah perekat kebersamaan dalam organisasi untuk mencapai tujuan, mengkoordinasikan aktivitas organisasi, dan mengarahkan perilaku yang diharapkan organisasi. Komunikasi organisasi yang terjadi dengan efektif akan mempermudah perawat untuk memberikan perhatian pada hal yang diprioritaskan dalam organisasi. Gillies (1996) menyebutkan bahwa perawat dapat mewujudkan sasaran yang berhubungan dengan pekerjaannya melalui kerja sama dan komunikasi secara efektif dengan rekan kerjanya. Penelitian Dehaghani (2010) mimperlihatkan hubungan yang signifikan antara komunikasi interpersonal kepala perawat dengan kepuasan kerja perawat. Penelitian Lolita (2004) menunjukkan komunikasi organisasi berkontribusi terhadap kepuasan kerja perawat.

Pengkajian di salah satu rumah sakit didapatkan indeks kepuasan pelayanan keperawatan pada triwulan 4 tahun 2010 terjadi penurunan di beberapa ruang rawat inap dan hasil evaluasi mutu asuhan keperawatan tahun 2009 melalui instrumen B Mutu Asuhan Keperawatan menunjukkan masih dibawah nilai standar mutu. Selain itu, hasil diskusi dengan 6 orang kepala ruangan juga menunjukkan terdapat hambatan komunikasi dalam pelayanan keperawatan. Masalah komunikasi yang terjadi antara lain kesalahpahaman dalam menerima informasi, perawat tertentu kurang memberi umpan balik dan di antara perawat kadang kurang terbuka untuk saling memberi masukan atau usulan. Keadaan penurunan kualitas pelayanan keperawatan berkaitan dengan peran perawat dalam memberikan pelayanan keperawatan. Evaluasi kinerja perawat dan identifikasi adanya masalah komunikasi dalam pelayanan keperawatan diperlukan sebagai pertimbangan untuk perbaikan kualitas pelayanan keperawatan agar tetap optimal.

\section{Metode}

Penelitian ini merupakan penelitian korelasi deskriptif dengan pendekatan potong lintang, bertujuan untuk melihat hubungan antara komunikasi organisasi dengan kinerja perawat pelaksana, dan mengidentifikasi faktor yang paling berpengaruh terhadap kinerja perawat pelaksana. Hipotesis yang dibuktikan dalam penelitian ini adalah "Ada hubungan antara komunikasi organisasi dengan kinerja perawat pelaksana di ruang rawat inap RS". Responden penelitian sebanyak 156 perawat pelakana. Instrumen yang digunakan adalah kuesioner yang dikembangkan oleh peneliti sesuai dengan teori terkait variabel yang diteliti yaitu kinerja perawat berdasarkan standar praktik profesional (ANA, 2004; PPNI, 2010) dan komunikasi organisasi berdasarkan pendekatan mikro (Masmuh, 2010; Muhammad, 2009). Analisis bivariat menggunakan uji chi square dan analisis multivariat menggunakan regresi logistik berganda untuk mengidentifikasi faktor komunikasi organisasi yang paling berpengaruh terhadap kinerja perawat pelaksana. Pengukuran Kinerja Perawat dan Komunikasi Organisasi menggunakan empat kriteria berdasarkan skala Likert, selanjutnya data dikelompokkan dalam dua kategori berdasarkan nilai median atau mean sesuai distribusi data. Prinsip etik memperhatikan hak responden untuk menentukan kesediaannya sebagai responden penelitian melalui pernyataan persetujuan. Peneliti menghormati hak subyek penelitian, dengan cara menjamin kerahasiaan identitas (anonymity), kebebasan pribadi (privacy), dan kerahasiaan data (confidentiality).

\section{Hasil}

Karakteristik responden pada penelitian ini sebagian besar berumur 32 tahun atau lebih, berada pada rentang 22-57 tahun dengan rrerata 33,67 tahun $(\mathrm{SD}=7,9)$. Sebagian besar responden perempuan $(98,1 \%)$, sudah menikah 
(75,6\%), dengan pendidikan sebagian besar D3 Keperawatan $(96,2 \%)$, dan lama kerja lebih dari 12 tahun $(37,2 \%)$.

Berdasarkan analisis data didapatkan bahwa proporsi perawat berkinerja kurang hampir sebanding dengan perawat berkinerja baik. Demikian juga proporsi komunikasi organisasi lemah hampir sebanding dengan komunikasi organisasi kuat (Gambar 1).

Kinerja perawat berdasarkan kemampuan perawat melakukan pengkajian, diagnosa keperawatan, perencanaan, dan implementasi menunjukkan kinerja kurang hampir sebanding dengan kinerja perawat baik yaitu proporsi kinerja kurang (>40\%). Kinerja perawat berdasarkan kemampuan perawat melakukan evaluasi baik didapatkan proporsi yang cukup tinggi yaitu 60,9\% (Tabel 1).

Hasil analisis menunjukkan komunikasi organisasi lemah cukup tinggi berdasarkan supervisi dan pengarahan, juga kepuasan kerja. Sedangkan proporsi komunikasi organisasi berdasarkan orientasi dan latihan, keterlibatan anggota dan penentuan iklim organisasi lemah (proporsi $>40 \%$ ) hampir sebanding dengan komunikasi organisasi kuat (Tabel 2).

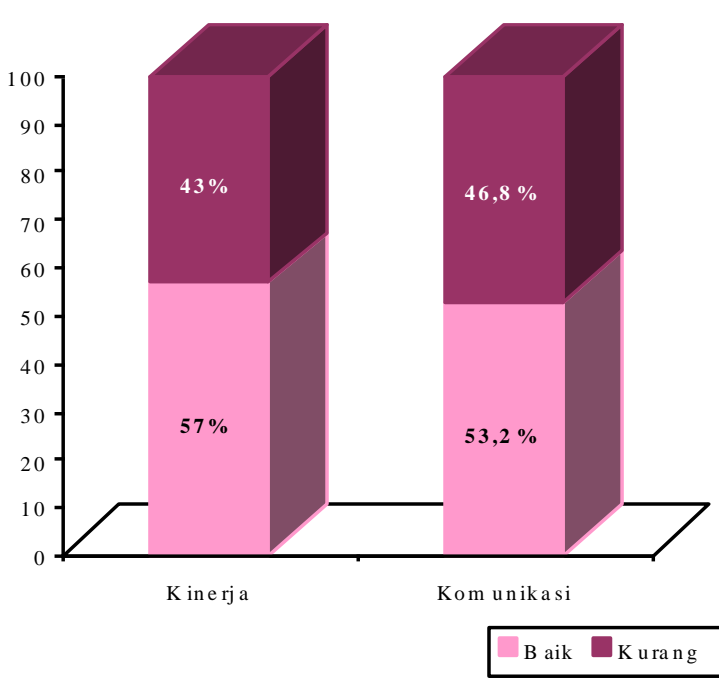

Gambar 1. Gambaran Kinerja Perawat Pelaksana dan Komunikasi Organisasi
Hasil analisis menunjukkan ada hubungan antara komunikasi organisasi dengan kinerja perawat pelaksana $(p=0,046 ; \alpha=0,05)$.

Tabel 1. Kinerja Perawat berdasarkan Kemampuan Melakukan Pengkajian, Diagnosa Keperawatan, Perencanaan, Implementasi, dan Evaluasi

\begin{tabular}{lcc}
\hline Variabel & $\begin{array}{c}\text { Frekuensi } \\
(\mathbf{n = 1 5 6 )}\end{array}$ & $\begin{array}{c}\text { Persentase } \\
(\mathbf{\%})\end{array}$ \\
\hline Pengkajian & 74 & 47,4 \\
Kurang & 82 & 52,6 \\
Baik & & \\
Diagnosa Kep & 84 & 53,8 \\
Kurang & 72 & 46,2 \\
Baik & & \\
Perencanaan & 73 & 46,8 \\
Kurang & 83 & 53,2 \\
Baik & & \\
Implementasi & & 48,1 \\
Kurang & 75 & 51,9 \\
Baik & 81 & \\
Evaluasi & & 39,1 \\
Kurang & & 60,9 \\
Baik & 61 & \\
\hline
\end{tabular}

Tabel 2. Komunikasi Organisasi berdasarkan Orientasi, Keterlibatan, Iklim Komunikasi, Supervisi, dan Kepuasan Kerja

\begin{tabular}{lcc}
\hline Variabel & $\begin{array}{c}\text { Frekuensi } \\
(\mathbf{n = 1 5 6})\end{array}$ & $\begin{array}{c}\text { Persentase } \\
(\%)\end{array}$ \\
\hline $\begin{array}{l}\text { Orientasi dan Latihan } \\
\text { Lemah }\end{array}$ & 70 & 44,9 \\
Kuat & 86 & 55,1 \\
Keterlibatan Anggota & & \\
Lemah & 73 & 46,8 \\
Kuat & 83 & 53,2 \\
Penentuan Iklim Komunikasi & & \\
Lemah & 76 & 48,7 \\
Kuat & 80 & 51,3 \\
& & \\
Supervisi dan Pengarahan & 110 & $70,5^{*}$ \\
Lemah & 46 & 29,5 \\
Kuat & & \\
Kepuasan Kerja & & \\
Lemah & 96 & $61,5^{*}$ \\
Kuat & 60 & 38,5 \\
\hline *Bermakna pada $\alpha=0,05$ & &
\end{tabular}

*Bermakna pada $\alpha=0,05$ 
Komunikasi organisasi berdasarkan orientasi dan latihan, supervisi dan pengarahan juga menunjukkan ada hubungan dengan kinerja perawat (Tabel 3).

Hasil analisis bivariat variabel karakteristik responden dengan kinerja perawat menunjukkan karakteristik responden berdasarkan umur berhubungan dengan kinerja perawat $(\mathrm{p}=0,021$; $\alpha=0,05)$. Demikian juga karakteristik responden berdasarkan lama kerja berhubungan dengan kinerja perawat $(p=0,041 ; \alpha=0,05)$ sedangkan jenis kelamin, status perkawinan dan pendidikan tidak berhubungan dengan kinerja perawat.

Analisis multivariat menunjukkan faktor yang paling berpengaruh terhadap kinerja perawat adalah supervisi dan pengarahan setelah dikontrol variabel keterlibatan anggota, status perkawinan, umur, dan lama kerja (Tabel 4).

Tabel 3. Hubungan Komunikasi Organisasi dan Kinerja Perawat Pelaksana

\begin{tabular}{|c|c|c|c|c|c|c|c|c|}
\hline \multirow{3}{*}{ Variabel } & \multicolumn{4}{|c|}{ Kinerja Perawat } & \multirow{2}{*}{\multicolumn{2}{|c|}{ Total }} & \multirow{3}{*}{$\begin{array}{c}\text { OR } \\
(\text { CI 95\%) }\end{array}$} & \multirow{3}{*}{$p$} \\
\hline & \multicolumn{2}{|c|}{ Kurang } & \multicolumn{2}{|c|}{ Baik } & & & & \\
\hline & $\mathbf{n}$ & $\%$ & $\mathbf{n}$ & $\%$ & $\mathbf{n}$ & $\%$ & & \\
\hline \multicolumn{9}{|l|}{ Komunikasi Organisasi } \\
\hline Lemah & 38 & 52,1 & 35 & 47,9 & 73 & 100,0 & 2,022 & $0,046^{*}$ \\
\hline Kuat & 29 & 34,9 & 54 & 65,1 & 83 & 100,0 & $(1,062-3,849)$ & \\
\hline \multicolumn{9}{|l|}{ Sub Variabel } \\
\hline \multicolumn{9}{|l|}{ Orientasi dan Latihan } \\
\hline Lemah & 37 & 52,9 & 33 & 47,1 & 70 & 100,0 & 2,093 & $0,036^{*}$ \\
\hline Kuat & 30 & 34,9 & 56 & 65,1 & 86 & 100,0 & $(1,097-3,992)$ & \\
\hline \multicolumn{9}{|l|}{ Keterlibatan Anggota } \\
\hline Lemah & 37 & 50,7 & 36 & 49,3 & 73 & 100,0 & 1,816 & 0,095 \\
\hline Kuat & 30 & 36,1 & 53 & 63,9 & 83 & 100,0 & $(0,956-3,447)$ & \\
\hline \multicolumn{9}{|c|}{ Penentuan Iklim Komunikasi } \\
\hline Lemah & 36 & 47,4 & 40 & 52,6 & 76 & 100,0 & 1,423 & 0,355 \\
\hline Kuat & 31 & 38,8 & 49 & 61,3 & 80 & 100,0 & $(0,753-2,688)$ & \\
\hline \multicolumn{9}{|l|}{ Supervisi dan Pengarahan } \\
\hline Lemah & 56 & 50,9 & 54 & 49,1 & 110 & 100,0 & 3,300 & $0,003 *$ \\
\hline Kuat & 11 & 23,9 & 35 & 76,1 & 46 & 100,0 & $(1,522-7,153)$ & \\
\hline \multicolumn{9}{|l|}{ Kepuasan Kerja } \\
\hline Lemah & 44 & 45,8 & 52 & 54,2 & 96 & 100,0 & 1,361 & 0,451 \\
\hline Kuat & 23 & 38,3 & 37 & 61,7 & 60 & 100,0 & $(0,705-2,627)$ & \\
\hline
\end{tabular}

*Bermakna pada $\alpha=0,05$

Tabel 4. Analisis Variabel Tahap Terakhir Faktor Paling Berpengaruh terhadap Kinerja Perawat Pelaksana

\begin{tabular}{lccccc}
\hline Variabel & $\mathbf{B}$ & $\mathbf{S E}$ & $\boldsymbol{p}$ & $\mathbf{O R}$ & $\mathbf{9 5}$ \% CI \\
\hline Supervisi dan Pengarahan & 1,040 & 0,418 & $0,013^{*}$ & 2,829 & $1,248-6,417$ \\
Keterlibatan anggota & 0,383 & 0,353 & 0,279 & 1,466 & $0,734-2,931$ \\
Status perkawinan & $-0,423$ & 0,462 & 0,359 & 0,655 & $0,265-1,618$ \\
Umur & 0,478 & 0,537 & 0,374 & 1,613 & $0,563-4,622$ \\
Lama kerja & & & 0,793 & & \\
Lama(1) & $-0,091$ & 0,540 & 0,866 & 0,913 & $0,317-2,630$ \\
Lama(2) & 0,241 & 0,719 & 0,738 & 1,272 & $0,311-5,204$ \\
\hline
\end{tabular}

*bermakna pada $\alpha=0,05$ 


\section{Pembahasan}

Hubungan komunikasi organisasi dengan kinerja perawat pelaksana. Hasil penelitian ini menunjukkan bahwa ada hubungan antara komunikasi organisasi dengan kinerja perawat. Didapatkan bahwa komunikasi organisasi yang lemah berisiko memberikan kinerja kurang dibandingkan komunikasi organisasi kuat. Hasil penelitian ini menggambarkan pentingnya komunikasi dalam organisasi sebagai kunci untuk mempererat anggota, sehingga saling tergantung dan bersama memberikan pelayanan yang terbaik. Hasil penelitian ini mendukung pernyataan bahwa komunikasi organisasi berkaitan dengan efektifitas partisipasi karyawan dalam melaksanakan program (Swansburg \& Swansburg, 1999) dan mendukung penelitian yang menunjukkan keterkaitan nilai komunikasi organisasi dengan tingginya kinerja organisasi (Goldhaber, 1993).

Lemahnya komunikasi organisasi yang terjadi dalam pelayanan keperawatan, dapat menjadi hambatan untuk mencapai tujuan organisasi sesuai dengan visi yang ditetapkan. Komunikasi yang lemah menggambarkan bahwa komunikasi belum terjadi secara efektif, yaitu penerimaan pesan atau informasi belum disertai adanya umpan balik dari penerima pesan. Komunikasi terjadi dengan efektif bila penerima pesan dapat menerima pesan dengan baik, mengerti, menggunakan, dan ada umpan balik (feedback) terhadap pesan yang diterima dari pemberi pesan (sender) (Shortell \& Kaluzny, 2005). Hasil penelitian menunjukkan perawat belum memberikan umpan balik secara optimal dan menilai informasi yang disampaikan oleh atasan belum dirasa memotivasi staf untuk berpartisipasi dalam pelayanan keperawatan secara optimal.

Persentase dari tiap subvariabel unsur komunikasi organisasi lemah masih cukup tinggi, terutama supervisi dan pengarahan. Hasil analisis juga menunjukkan adanya hubungan subvariabel komunikasi organisasi supervisi dan pengarahan dengan kinerja perawat. Selanjutnya disimpulkan bahwa supervisi dan pengarahan lemah berisiko untuk mendapatkan kinerja kurang dibandingkan supervisi dan pengarahan kuat. Pelaksanaan supervisi dan pengarahan penting dilakukan dengan cara komunikasi yang efektif sehingga memungkinkan staf perawat dapat termotivasi menunjukkan kinerja yang tinggi. Hasil penelitian ini mendukung pernyataan bahwa supervisi dan pengarahan dapat membantu individu melakukan pekerjaan sebaik mungkin (Muhammad, 2009; Masmuh, 2010).

Proporsi unsur komunikasi organisasi supervisi dan pengarahan lemah, bila dicermati didapatkan satu pernyataan yang paling lemah yaitu perawat menyatakan bahwa supervisi dan pengarahan yang dilakukan atasan lebih dirasakan sebagai tuntutan daripada memberikan masukan yang bermanfaat untuk perbaikan. Hal ini menggambarkan bahwa supervisi dan pengarahan dianggap sebagai tekanan oleh staf perawat, sehingga kurang optimal memberikan pelayanan keperawatan. Perasaan tertekan ini apabila tidak diperhatikan oleh atasan atau manajemen akan semakin memperburuk kinerja individu karena perawat melakukan pekerjaan secara terpaksa tanpa disertai nilai yang terkandung dalam pelayanan.

Unsur komunikasi organisasi yaitu orientasi dan latihan berhubungan dengan kinerja perawat. Orientasi dan latihan yang lemah berisiko untuk memberikan kinerja kurang dibandingkan orientasi dan latihan kuat. Hasil penelitian mendukung pernyataan bahwa orientasi dan latihan yang diberikan hendaknya membantu perawat agar dapat menyesuaikan diri dan meningkatkan produktivitas (Swansburg \& Swansburg, 1999). Dengan demikian, komunikasi pada saat orientasi dan latihan yang kuat dapat dipahami oleh staf perawat, sehingga berkontribusi membantu perawat untuk melakukan pekerjaannya dengan baik.

Proporsi unsur komunikasi organisasi yaitu orientasi dan latihan lemah, bila dicermati didapatkan satu pernyataan yang paling lemah, yaitu perawat menyatakan bahwa kesempatan staf perawat untuk bertanya atau memberi respon saat orientasi dan latihan sangat terbatas. Hal ini memberikan gambaran bahwa perawat 
mengharapkan adanya kesempatan yang lebih untuk memberikan respon pada saat orientasi dan latihan. Respon atau umpan balik dapat berupa pertanyaan atau masukan dari staf perawat untuk mendapat kejelasan terhadap pesan yang disampaikan sehingga pesan lebih dapat dipahami. Seperti yang ditekankan oleh Marquis dan Huston (2009) manajer sebaiknya mencari umpan balik apakah komunikasi diterima dengan benar.

Unsur komunikasi organisasi yaitu keterlibatan anggota tidak berhubungan dengan kinerja perawat. Hal ini tidak sesuai dengan pernyataan bahwa keterlibatan anggota akan meningkatkan atau memperbaiki kebiasaan kerja (Swansburg \& Swansburg, 1999). Menurut peneliti keterlibatan anggota dalam pelayanan keperawatan tidak memberikan pengaruh yang besar terhadap pencapaian kinerja perawat. Hal ini dimungkinkan karena faktor lain bahwa perawat menyadari tanggung jawabnya dalam pekerjaan, sehingga berupaya memberikan kinerja yang tinggi bukan karena dimotivasi untuk terlibat.

Unsur komunikasi organisasi yaitu penentuan iklim komunikasi tidak berhubungan dengan kinerja perawat. Hal ini tidak sesuai dengan pernyataan bahwa penentuan iklim komunikasi dapat menyebabkan bawahan tidak produktif (Muhammad, 2009; Masmuh, 2010). Menurut peneliti penentuan iklim komunikasi bukan satu-satunya yang membuat kinerja perawat kurang. Perawat berupaya memberikan kinerja yang tinggi meskipun iklim komunikasi dirasa kurang mendukung, namun ada kemungkinan perawat menunjukkan kinerja tinggi karena hal lain atau terpaksa.

Unsur komunikasi organisasi yaitu kepuasan kerja berkaitan dengan komunikasi organisasi tidak berhubungan dengan kinerja perawat. Hal ini tidak mendukung pernyataan bahwa perasaan puas karena pemberian informasi yang cukup membuat karyawan melakukan pekerjaan dengan baik (Masmuh, 2010; Muhammad, 2009). Menurut peneliti perasaan puas karena pemberian informasi bukan satusatunya yang membuat kinerja perawat kurang.
Perawat berupaya memberikan kinerja tinggi karena faktor lain seperti kesadaran dalam tanggungjawab pekerjaan atau tuntutan dalam pekerjaan.

\section{Hubungan Karakteristik Perawat dengan Kinerja Perawat Pelaksana. Berdasarkan hasil} penelitian didapatkan ada hubungan antara umur dengan kinerja perawat. Analisis selanjutnya disimpulkan bahwa perawat yang umur kurang dari 32 tahun berisiko lebih besar berkinerja kurang dibandingkan perawat yang umurnya lebih dari 32 tahun. Hasil penelitian ini mendukung penelitian Kanestren (2009) yang menyatakan bahwa umur berhubungan dengan kinerja perawat. Umur pada penelitian ini merupakan faktor individu yang cukup penting diperhatikan karena berhubungan dengan kinerja sesuai yang diungkapkan oleh Hasibuan (2003), yaitu umur individu mempengaruhi kemampuan kerja seseorang.

Berdasarkan hasil penelitian didapatkan lama kerja berhubungan dengan kinerja perawat. Hasil penelitian ini mendukung penelitian (Kanestren, 2009) yang menyatakan bahwa lama kerja berhubungan dengan kinerja perawat. Hal ini juga sesuai dengan pernyataan bahwa semakin lama seseorang berkarya dalam suatu organisasi akan semakin tinggi produktivitasnya (Siagian, 2009). Analisis selanjutnya disimpulkan bahwa perawat dengan lama kerja kurang dari tujuh tahun berisiko lebih besar kinerjanya kurang dibandingkan perawat dengan lama kerja 7-12 tahun, dan berisiko lebih besar kinerjanya kurang dibandingkan perawat dengan lama kerja lebih dari 12 tahun. Hal ini menggambarkan bahwa pengalaman seseorang dalam bekerja turut berkontribusi terhadap kinerja.

Penelitian ini tidak menemukan hubungan antara karakteristik perawat berupa jenis kelamin, status perkawinan dan pendidikan dengan kinerja perawat. Hasil ini berbeda dengan anggapan bahwa jenis kelamin berkaitan dengan kinerja, yaitu wanita lebih bertanggung jawab terhadap kebutuhan rumah tangga sehingga mempengaruhi tingkat kehadiran (Robbins, 2003/2006). Menurut peneliti, baik perawat 
perempuan dan laki-laki mempunyai tanggung jawab yang sama untuk menampilkan hasil kerja secara optimal dalam pelayanan keperawatan sesuai dengan ketentuan atau standar praktik profesional.

Berdasarkan hasil penelitian didapatkan status perkawinan perawat tidak ada hubungan dengan kinerja perawat. Hasil ini mendukung penelitian (Lumbantoruan, 2005), namun berbeda dengan ungkapan bahwa status perkawinan menimbulkan terjadinya peningkatan tanggung jawab sehingga pekerjaan menjadi lebih berharga dan penting (Robbins, 2003/2006). Peningkatan tanggung jawab perawat dalam pekerjaan karena motivasi dan kematangan pribadi terhadap nilai dalam pelayanan keperawatan.

Penelitian ini menggambarkan tingkat pendidikan perawat tidak berhubungan dengan kinerja perawat. Hasil ini mendukung Burdahyat (2009) dan Sari (2009), namun berbeda dengan Robbins (2003/2006) yang menyatakan kemampuan intelektual individu berkaitan dengan indikator perkiraan kuat untuk kinerja. Diasumsikan sebagian perawat dengan pendidikan D3 Keperawatan menunjukkan kinerja baik karena motivasi dan tanggung jawab untuk memberikan pelayanan keperawatan yang optimal.

\section{Faktor yang Paling Berpengaruh terhadap} Kinerja Perawat Pelaksana. Supervisi dan pengarahan merupakan variabel yang paling berpengaruh terhadap kinerja perawat. Perawat dengan supervisi dan pengarahan yang lemah berisiko kinerjanya kurang setelah dikontrol keterlibatan anggota, status perkawinan, umur dan lama kerja. Hasil penelitian menggambarkan bahwa supervisi dan pengarahan yang dilakukan dengan cara komunikasi yang kurang efektif akan berkontribusi besar pada kinerja perawat yang kurang.

Perawat menilai bahwa informasi mengenai supervisi dan pengarahan kurang diterima dengan baik sehingga supervisi dan pengarahan dirasa sebagai tuntutan dan kurang bermanfaat. Supervisi dan pengarahan yang dilakukan atasan dengan demikian kurang memotivasi perawat untuk partisipasi dalam meningkatkan kualitas pelayanan.

Supervisi dan pengarahan yang oleh manajer membantu proses pemahaman dan tanggung jawab karyawan dalam melaksanakan pekerjaan. Manajer dengan komunikasi yang efektif menyampaikan pesan dan memberikan pengarahan secara tepat, sehingga mudah bagi karyawan untuk mengerti dan memaknai pesan. Supervisi dan pengarahan didasarkan pada perencanaan yang telah dibuat dengan tujuan untuk mencapai tujuan organisasi.

\section{Kesimpulan}

Hasil penelitian ini menunjukkan komunikasi organisasi berhubungan dengan kinerja perawat pelaksana. Variabel komunikasi organisasi yaitu supervisi dan pengarahan merupakan variabel yang paling berpengaruh terhadap kinerja perawat. Supervisi dan pengarahan apabila tidak dilakukan dengan cara-cara komunikasi yang efektif berisiko besar memberikan kinerja perawat kurang dibandingkan supervisi dan pengarahan kuat. Komunikasi organisasi dalam pelayanan keperawatan sebagai kunci keberhasilan dalam manajemen membantu staf keperawatan mengerti dan memahami pekerjaannya lebih baik sehingga menunjukkan kualitas yang tinggi dalam pelayanan keperawatan. Upaya meningkatkan komunikasi organisasi dengan cara melakukan supervisi dan pengarahan sesuai pedoman perlu dilakukan, sehingga dihasilkan kinerja perawat yang semakin baik. Hubungan kinerja perawat dengan komunikasi organisasi yang lebih detil dapat diteliti lebih lanjut dengan pendekatan komunikasi organisasi secara makro yang mencakup struktur global dalam organisasi (MS, RR, KN).

\section{Referensi}

ANA. (2004). Standards of professional nursing practice. Diperoleh dari: http://www.statepen. org/ana.htm.

Burdahyat. (2009). Hubungan budaya organisasi dengan kinerja perawat di RSUD Sumedang 
tahun 2009 (Tesis, tidak dipublikasikan). Fakultas Ilmu Keperawatan Universitas Indonesia, Jakarta.

Dehaghani, A.R., Hosseini, H., Tavakol, K., \& Bakhtiyari, S. (2010). Relationship between communication manners of head nurses with job satisfaction of nurses under their supervision in educational hospitals of Isfahan University of Medical Sciences in 2006. IJNMR, 15 (2), 43-47.

Fried, B.J., \& Fottler, M.D.(2008). Human resources in healthcare: Managing for success (3rd Ed.). Chicago: Health Administration Press.

Gillies, D.A. (1996). Nursing management: A system approach. Philadelphia: W.B. Saunders Company.

Goldhaber, G.M. (1993). Organizational communication (7th Ed.). NewYork: McGraw-Hill.

Hasibuan, M.S.P. (2003). Manajemen sumber daya manusia (Edisi Revisi, Cet. 13). Jakarta: Bumi Aksara.

Ivancevich, J.M. (1999). Organizational behavior and management (5th Ed.). Singapore: McGraw-Hill.

Kanestren, D.R. (2009). Analisis hubungan karakteristik individu dan lingkungan kerja dengan kinerja perawat di unit rawat inap $R S$ Pertamina Jaya (Tesis, tidak dipublikasikan). Fakultas Kesehatan Masyarakat Universitas Indonesia, Jakarta.

Lolita, W. (2004). Kontribusi komunikasi organisasi dan karaktersistik perawat pelaksana terhadap kepuasan kerja perawat pelaksana di RS ketergantungan obat Jakarta. (Tesis, tidak dipublikasikan). Fakultas Ilmu Keperawatan Universitas Indonesia, Jakarta.
Lumbantoruan, L. (2005). Analisis hubungan antara iklim kerja dan karakteristik individu dengan kinerja perawat di ruang rawat inap RSUP H. Adam Malik Medan (Tesis, tidak dipublikasikan). Fakultas Ilmu Keperawatan Universitas Indonesia, Jakarta.

Marquis, B.L., \& Huston, C.J. (2009). Leadership roles and management function in nursing: Theory \& application (6th Ed.). Philadelphia: Lippincott.

Masmuh, A. (2010). Komunikasi organisasi dalam perspektif teori dan praktek (Cet. 2). Malang: Universitas Muhammadiyah Malang.

Muhammad, A. (2009). Komunikasi organisasi (Edisi 1, Cet. 10). Jakarta: Bumi Aksara.

PPNI. (2010). Standar profesi dan kode etik Perawat Indonesia. Jakarta: PPNI.

Robbins, S.P. (2006). Perilaku organisasi. Ed. 10. (Alih bahasa B. Molan). Jakarta: PT Indeks. Buku asli diterbitkan tahun 2003.

Sari, M.T. (2009). Hubungan budaya organisasi dan gaya kepemimpinan kepala ruangan dengan kinerja perawat di RSUD Raden Mataher, Jambi (Tesis, tidak dipublikasikan). Fakultas Ilmu Keperawatan Universitas Indonesia, Jakarta.

Shortell, S.M., \& Kaluzny, A.D. (2005). Health care management (5th Ed.). New York: DNLM.

Siagian, S.P. (2009). Manajemen sumber daya manusia (Edisi 1, Cet. 17). Jakarta: Bumi Aksara.

Swansburg, R.C., \& Swansburg, R.J. (1999). Intoductory management and leadership for nurses (2nd Ed.). Vancouver: Jones \& Bartlett. 